\title{
Clinical Study: Effect of Supplementation with High Genistein Soybean Isoflavones and Pumpkin Standardized Extract on Urinary Incontinence in Western Perimenopausal Women
}

\author{
Marañón JA ${ }^{1 *}$, Lozano $C^{2}$, Martínez-Campesino L², de Los Santos $\mathrm{L}^{2}$, Bank $\mathrm{G}^{3}$ and Caballero-Garrido $\mathrm{E}^{4}$ \\ ${ }^{1}$ Tradichem SL (Innovation Center), Spain \\ ${ }^{2}$ Arganda del Rey Madrid, Spain \\ ${ }^{3}$ Full Spectrum Consulting, USA \\ ${ }^{4}$ Department of Neurosurgery, University of New Mexico, USA \\ Submission: March 15, 2017; Published: April 12, 2017 \\ *Corresponding author: Jose Angel Marañón, Tradichem SL (Innovation Center), Parque Centífico de MADRID, Faraday 7, Edificio CLAID, Campus \\ Cantoblanco, Universidad Autónoma de Madrid, 28049, Madrid, Spain, Email: jmaranon@tradichem.es
}

\begin{abstract}
Objective: To examine the effect of supplementation of a novel combination of high genistein soybean extract and pyrogallol plus polyphenols from standardized pumpkin seed extract in perimenopausal women with urinary (UI) incontinence.

Methods: The present study investigated the effects of a dietary supplement formula containing high genistein soybean extract and pumpkin seed extract (DROPSORDRY ${ }^{\mathrm{TM}}$ ) on 82 perimenopausal women diagnosed with urinary incontinence. Subjects received 2 tablets of DROPSORDRY ${ }^{\mathrm{TM}}$ per day for 4 weeks, followed by 1 tablet per day for an additional 4 weeks. Subjects recorded UI symptoms and quality of life before supplementation for 14 days and for 8 weeks during treatment. Paired difference test (Wilcoxon test) was used to determine if there was a significant improvement in UI symptoms before and after treatment.
\end{abstract}

Results: Compared to baseline data, statistically significant decreases were observedin mean urgency grade $(24.7 \%$; $\mathrm{P}<0.01)$, nocturia $(69.35 \%$; $\mathrm{P}<0.05)$ and the use of daily pantyliners $(66.25 \%$; $\mathrm{p}<0.01)$. In addition, in the quality of life was improved in $92.3 \%$ of the subjects.

Conclusion: The results suggest that DROPSORDRY ${ }^{\mathrm{TM}}$ supplementation is a safe and an effective strategy for reducing urinary incontinence symptoms and quality of life in Western perimenopause women.

Keywords: Dietary supplements; Urinary incontinence; Perimenopause; Genistein; Pyrogallol; Soybean extract; Pumpkin seed extract; Stress urinary incontinence (SUI)

\section{Introduction}

Urinary incontinence (UI) is a significant health problem with considerable social and economic impact. According to the National Association for Continence, UI affects over 25 million people in the U.S., of which $75-80 \%$ are women [1]. UI affects women of all ages, and risk factors include pregnancy, childbirth, body mass index, previous hysterectomy and menopause [2]. The prevalence of UI also increases with age [3].

UI is divided into three major subtypes. Stress urinary incontinence (SUI) is defined as involuntary loss of urine resulting from physical exertion, or from sneezing or coughing.
Urgency urinary incontinence (UUI) is involuntary leakage accompanied by the sudden need to pass urine. UUI will also manifest as frequency and nocturia (frequent urination at night). Mixed urinary incontinence is a combination of both [4,5]. When UI is combined with frequency and urge (or both), it is described as Overactive bladder syndrome (OAB). OAB affects an estimated $7.6 \%$ of women in the U.S [6].

UI and OAB result in significant decrease in quality of life $[3,4,7,8]$, and a number of studies have also indicated that UI results in substantial economic burden [7,9]. One analysis 
reported that a patient's willingness to pay for improvement exceeds routine care costs by 3-7 times. Therefore effective treatment may be economically beneficial as well as improving quality of life. 7 Current treatment for UI includes pelvic floor muscle training, surgery, and anti-muscarinic medications. Antimuscarinic medications block the action of acetylcholine on the muscarinic receptors located in the epithelial lining of the bladder, thereby reducing abnormal bladder contractions. The overall efficacy and tolerability profile of these medications is reported to be less than optimal, as side effects such as constipation and dry mouth are common [10].

The etiology of UI varies between subtype with SUI caused by sphincter weakness and UUI a result of over activity of the detrusor muscle, the smooth muscle that lines the wall of the bladder. This over activity may be caused by inflammation, infection or loss of neurological control of detrusor contractions via the muscarinic receptors $[10,3]$. In the case of menopause and perimenopause, other physiological changes also increase the risk of UI. The decline in estrogen occurring during these stages is believed to play a role, as the bladder is rich in estrogen receptors [11]. Conversely, muscarinic receptors generally increase during menopause [12]. Morphological changes in estrogen sensitive tissue, such as thinning and atrophy of the urethral muscle and connective tissue, also affect continence [13]. While in theory, hormonal replacement therapy (HRT) might help reverse the estrogen decline, it has shown mixed results in treating UI associated with menopause $[11,13,14]$. In fact, in studies have shown that exogenous estrogen worsens incontinence in postmenopausal women [15-17]. In addition, HRT is associated with risks of breast, endometrial and ovarian cancers as well as dementia and cardiovascular diseases [18].

Pelvic floor muscle training is one non-pharmaceutical treatment for UI. However, it has been shown to be less effective in women early menopause and in the late menopausal transition [19]. In addition, many women transitioning to menopause may not seek out treatment for UI [20]. Therefore, there is much need for safe alternative treatment for UI associated with menopausal transition stages that does not require treatment from a physician or compliance to exercise therapy.

\section{Materials and Methods}

\section{Participants}

Eighty-two perimenopausal women diagnosed with urinary incontinence (42-62 years, mean 52 years) were enrolled in this study. The presence of UI was previously diagnosed using the International Continence Society standards (ICS). Subjects were excluded if they had allergies to the treatment ingredients, were pregnant or lactating, had previously diagnosed heart disease or were currently under pharmacological treatment. Documented informed consent was obtained from all patients prior to the study and the study was performed in accordance with international ethical standards of Helsinki Declaration, and the research protocol was approved by the Comission of Bioetics, and Biosafety of Universidad de Extremadura, Merida, Spain.

\section{Procedure and measures}

This study was a single-center, not randomized open prospective study. Daily dosage was 2 tablets per day (500 mg of active material) from 0 to 4 week (T1). At week 4 , the dosage was reduced to $500 \mathrm{mg} /$ day daily intake for an additional 4 weeks (T2). Subjects were instructed to keep a micturition diary, following the International Consultation on Incontinence Questionnaire (ICIQ), before supplementation (T0) for 14 days, and for 8 weeks during treatment. The subjects monitored the time and amount of urine produced during a 24-hour period, urgency score (0-4), each incident of urine leakage due to urge or stress, and use of panty liners. The impact of symptoms of incontinence on quality of life and outcome of treatment was also assessed. A physician also evaluated each patient's micturition diary every three days, recording day, night and total frequency, day, night and total volume, episodes and grades of urgency per day, episodes on incontinence per day (stress and urge) and volume of urine over 24 hours and at night.

\section{Materials}

DROPSORDRY $^{\mathrm{TM}}$ is a dietary supplement in tablet form consisting of $500 \mathrm{mg}$ of a mixture of high-genistein soybean extract (SOLGEN $^{\mathrm{TM}}$, Tradichem SL, Madrid, Spain) and a proprietary pumpkin seed extract (TradichemSL, Madrid, Spain), providing $22,5 \mathrm{mg}$ total of total isoflavones ( 9 mggenistein plus genistin), $6.5 \mathrm{mg}$ pyrogallol and $8.75 \mathrm{mg}$ enterodiol per tablet. The tablet also contained excipients/binders including microcrystalline cellulose, silicon dioxide, magnesium stearate, hydroxypropyl methylcellulose, stearic acid and titanium dioxide. Tablets were manufactured by Eladiet S.A. Poli. Ind. Sud el Papiol, Salvador Espriu, 32, 08754 El Papiol, Barcelona. SPAIN

\section{Statistical analyses}

Descriptive statistics, mean \pm standard deviation, were used to summarize the data from the micturition diary. Paired difference test (Wilcoxon test) was used to determine if there was a significant improvement in the mean values of daily and nocturnal frequency, urgency grade score, UUI, SUI and number of daily pantyliners used between T0 and T2. Statistical significance was set at a P value of 0.05 .

\section{Results}

After eight weeks of treatment, the mean urgency grade score was reduced by $24.7 \%(\mathrm{P}<0.01)$ compared to baseline. Nocturia was reduced by $69.35 \%(\mathrm{p}<0.05$, Figure 1 ) compared to baseline and the use of daily pantyliners was reduced by $66.25 \%$ $(\mathrm{p}<0.01$, Figure 2) compared to baseline. There was a trend in the reduction of SUI. In addition, in the quality of life portion of the questionnaire, $96.2 \%$ of subjects reported satisfaction with the treatment and $92.3 \%$ reported improvement in quality of life. No side effects were reported. 


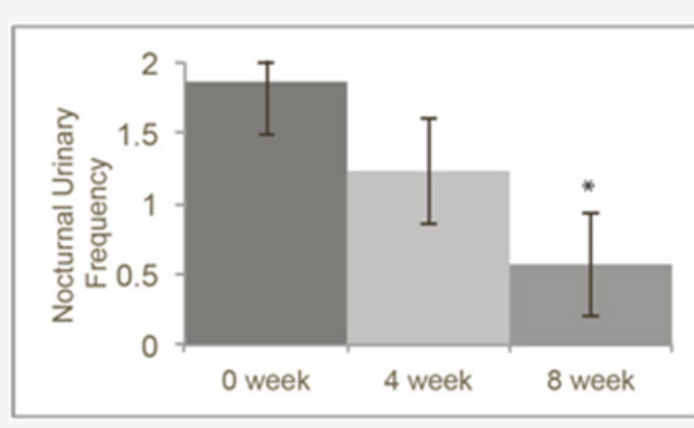

Figure 1: Effect of DROPSORDRY on nocturia. ${ }^{*}: p>0.01$

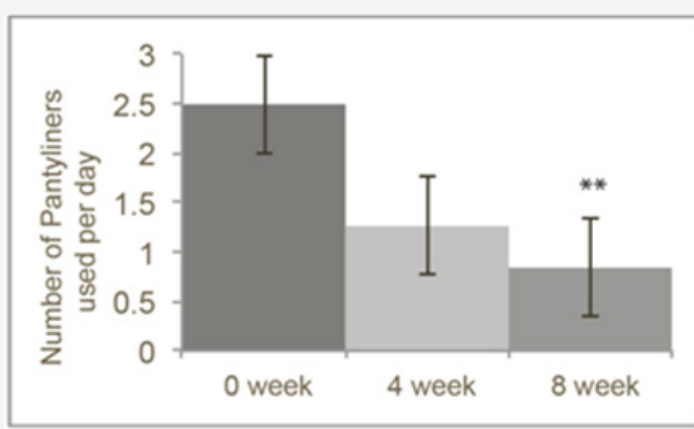

Figure 2: Effect of DROPSORDRY on number of pantyliners used per day.

${ }^{* *}: p>0.05$

\section{Discussion}

The present study investigated the effects of a dietary supplement, DROPSORDRY' ${ }^{\mathrm{TM}}$, on urinary incontinence in perimenopausal women. There were a number of key finding. First, statistically significant decreases were observed in two major symptoms of UI-mean urgency grade, nocturia. In addition, there was a statistically significant decrease in the use of daily panty liners, indicating a reduction of involuntary urine loss. A reduction trend was also observed in stress urinary incontinence. Finally, the majority of subjects also reported improvement in quality of life and overall satisfaction of the treatment; therefore, the present study's findings indicate that DROPSORDRY ${ }^{\mathrm{TM}}$ can be an effective treatment to reduce urinary incontinence symptoms in perimenopausal women within 8 weeks.

Changes in hormonal patterns during the transition between perimenopause and menopausemay explain the increase in prevalence of incontinence among women between the ages of 45 and 55 years [21]. Phytoestrogens have emerged as a natural alternative for treating menopausal and perimenopausal symptoms. Unlike HRT, phytoestrogens do not increase cancer or cardiovascular disease risk. In fact, phytoestrogens have shown protective effects against cancer and cardiovascular disease, as well as numerous other health benefits [18]. Soy is rich in phytoestrogens, particularly soy isoflavones, and has been shown to exert positive estrogenic effects and reducing some menopausal symptoms such as hot flashes [22] and loss of bone mineral density [23]. Genistein, which has structural similarities to $17 \beta$-estradiol (E2), has been shown in animal models to reduce the expression of muscarinic receptors M2 and M3 expression on the bladder wall. In addition, genestein therapy also reduced morphological changes that contribute to UI, such as increased collagen connective tissue and degenerative changes to the bladder [12].

Circulating levels of androgens also gradually decrease with age in postmenopausal women [24]. Androgen receptors are also expressed in the pelvic floor and lower urinary tract. Studies have also shown that androgens, like testosterone, have a muscle-building effect on these muscles [25]. Since testosterone is normally converted to estradiol by the enzyme aromatase, inhibition of aromatase may help maintain testosterone levels. Pumpkin seed extracts and oil have been shown to inhibit aromatase [26]. Which may explain why it has been used in folk medicine to treat kidney, bladder and prostate disorders [27] Pumpkin seed oil has also been shown to improve symptoms of overactive bladder [28]. Pumpkin seed extract in combination with soybean extracts have been shown to have promising potential treat urinary tract complications including SUI, overactive bladder, frequency and nocturia [29-32]. This study differs in that it focused solely on urinary incontinence in perimenopausal women using a novel formula containing a soybean extract containing a high level of genistein in combination with a proprietary standardized pumpkin seed extract. Moreover, this is the first clinical study conducted in Western women with occidental diet and non soy based diet.

\section{Conclusion}

The results of this present study suggest that the combination of phytoestrogens, particularly genistein, plus pyrogallol from pumpkin seed, provide safe and effective estrogenic and androgenic activity. This combination appears to help protect against both biochemical and morphological changes that occur in menopausal transition that increase the risk of urinary incontinence, resulting in relief of UI symptoms and improved quality of life in perimenopausal women.

\section{References}

1. https://www.nafc.org/

2. Kılıç M (2016) Incidence and risk factors of urinary incontinence in women visiting Family Health Centers. Springer Plus 5(1): 1331.

3. Khandelwal C, Kistler C (2013) Diagnosis of Urinary Incontinence. Am Fam Physician 87(8): 54455.

4. Faiena I, Patel N, Parihar JS, Calabrese M, Tunuguntla H (2015) Conservative Management of Urinary Incontinence in Women. Rev Urol 17(3):129-139.

5. Marinkovic SP, Gillen LM, Stanton SL (2004) Managing nocturia. BMJ 328(7447): 1063-1066. 
6. Coyne KS, Payne C, Bhattacharyya SK, Revicki DA, Thompson C, et al. (2004) The impact of urinary urgency and frequency on health-related quality of life in overactive bladder: results from a national community survey. Value Health 7(4): 455-463.

7. Minassian VA, Devore E, Hagan K, Grodstein F (2013) Severity of Urinary Incontinence and Effect on Quality of Life in Women, by Incontinence Type. Obstet Gynecol 121(5): 1083-1090.

8. Subak LL, Brown JS, Kraus SR, Brubaker L, Lin F, et al. (2006) Diagnostic Aspects of Incontinence Study (DAISy) Group. The "costs" of urinary incontinence for women. Obstet Gynecol 107(4): 908.

9. Coyne KS, Wein A, Nicholson S, Kvasz M, Chen CI, et al. (2014) Economic burden of urgency urinary incontinence in the United States: a systematic review. J Manag Care Pharm 20(2): 130-140.

10. Hegde SS (2006) Muscarinic receptors in the bladder: from basic research to therapeutics. Br J Pharmacol 147(Suppl 2): S80-S87.

11. Hillard T (2010) The postmenopausal bladder. Menopause Int 16(2): 74-80.

12. Turgut A, Goruk NY, Sak ME, Deveci E, Akdemir F, et al. (2014) Effects of genistein, estrogen and progesterone on bladder morphology and M2, M3 receptor expressions in oophorectomized rats. Acta Medica Mediterranea 30(4): 907-916.

13. Henn IW (2010) Menopause and its effect on the female lower urinary tract. SA Fam Pract 52(5): 405-408.

14. Quinn SD, Domoney C (2009) The effects of hormones on urinary incontinence in postmenopausal women. Climacteric 12(2): 106-113.

15. Hendrix SL, Cochrane BB, Nygaard IE, Handa VL, Barnabei VM, et al. (2005) Effects of estrogen with and without progestin on urinary incontinence. JAMA 293(8): 935-948.

16. Grady D, Brown JS, Vittinghoff E, Applegate W, Varner E, et al. (2001) Postmenopausal hormones and incontinence: the Heart and Estrogen/ Progestin Replacement Study. Obstet Gynecol 97(1):116-120.

17. Steinauer JE, Waetjen LE, Vittinghoff E, Subak LL, Hulley SB, et al. (2005) Postmenopausal hormone therapy: does it cause incontinence? Obstet Gynecol 106(5): 940-945.

18. Gencel VB, Benjamin MM, Bahou SN, Khalil RA(2012) Vascular Effects of Phytoestrogens and Alternative Menopausal Hormone Therapy in Cardiovascular Disease. Mini Rev Med Chem 12(2): 149-174.

19. Tosun OC, Mutlu EK, Tosun G, Ergenoglu AM, Yeniel Ao, et al. (2015) Do stages of menopause affect the outcomes of pelvic floor muscle training? Menopause 22(2): 175-184.

20. Waetjen LE, Xing G, Johnson WO, Melnikow J, Gold EB (2015) Factors
Associated With Seeking Treatment for Urinary Incontinence During the Menopausal Transition. Obstet Gynecol 125(5): 1071-1079.

21. Hunskaar S, Arnold EP, Burgio K, Diokno AC, Herzog AR, et al. (2000) Epidemiology and natural history of urinary incontinence. IntUrogynecol J Pelvic Floor Dysfunct 11(5): 301-319.

22. Howes LG, Howes JB, Knight DC (2006) Isoflavone therapy for hot flushes: A systematic review and meta-analysis. Maturitas 55(3): 203211.

23. Ma DF, Qin LQ Wang PY, Katoh R (2008) Soy isoflavone intake increases bone mineral density in the spine of menopausal women: Meta-analysis of randomized controlled trials. Clin Nutr 27(1): 57-64.

24. Yasui T, Matsui S, Tani A, Kunimi K, Yamamoto S, et al. (2012) Androgen in postmenopausal women. J Med Invest 59(1-2): 12-27.

25. Ho MH, Bhatia NN, Bhasin S (2004) Anabolic effects of andorgens on muscle of the female pelvic floor and lower urinary tract. Curr Opin Obstet Gynecol 16(15): 4059 .

26. Fruhwirth G, Hermetter A (2007) Seeds and oil of the Styrian oil pumpkin: Components and biological activities. Eur J Lipid Sci Technol 109: 1128-1140.

27. Medjakovic S, Hobiger S, Ardjomand-Woelkart K, Bucar F, Jungbauer A (2016) Pumpkin seed extract: Cell growth inhibition of hyperplastic and cancer cells, independent of steroid hormone receptors. Fitoterapia 110: $150-156$

28. Nishimura M, Ohkawara T, Sato H, Takeda H, Nishihira J (2014) Pumpkin Seed Oil Extracted From Cucurbita maxima Improves Urinary Disorder in Human Overactive Bladder. J Trad Complement Med 4(1): 72-74.

29. Yanagisawa E, Satoh I (2003) Study of effectiveness of mixed processed food containing Cucurbitapepo seed extract and soybean seed extract on stress urinary incontinence in women. Jpn J Med Pharm Sci 14(3): 313-322.

30. Shim B, Jeong H, Lee S, Hwang S, Moon B, et al. (2014) A randomized double-blind placebo-controlled clinical trial of a product containing pumpkin seed extract and soy germ extract to improve overactive bladder-related voiding dysfunction and quality of life. J Funct Foods 8: 111-117.

31. Sogabe H, Terado T (2001) Open clinical study of effects of pumpkin seed extract/soybean germ extract mixture-containing processed food on nocturia. Jpn J Med Pharm Sci 46: 727737.

32. Terado T, Sogabe H, Saito K (2004) Clinical study of mixed processed foods containing of pumpkin seed extract and soybean germ extract on pollakiuria in night in eldermen. Jpn J Med Pharm Sci 52: 551561.

\section{Your next submission with Juniper Publishers} will reach you the below assets

- Quality Editorial service

- Swift Peer Review

- Reprints availability

- E-prints Service

- Manuscript Podcast for convenient understanding

- Global attainment for your research

- Manuscript accessibility in different formats

( Pdf, E-pub, Full Text, Audio)

- Unceasing customer service

Track the below URL for one-step submission https://juniperpublishers.com/online-submission.php 